\title{
THE SPECIFICITIES OF USING CRYPTOCURRENCY IN PURCHASE AND SALE CONTRACTS
}

\author{
Oleksii Drozd ${ }^{1}$, Oleg Basai' ${ }^{2}$, Hanna Churpita ${ }^{3}$ \\ National Academy of Internal Affairs, Ukraine
}

\begin{abstract}
The aim of the article is to study the theoretical and legal possibilities of using cryptocurrency in purchase and sale contracts, to determine the specificities of such a phenomenon as cryptocurrency (Bitcoin) from the perspective of jurisprudence, and to draw attention of legal scholars primarily to possible further scientific researches on the introduction of this phenomenon in the modern civilian legislation of Ukraine. The subject of the study is the specificities of using cryptocurrency in contracts of purchase and sale. Methodology. The research is based on an analysis of legal acts on the legal regulation of cryptocurrency in Ukraine. By means of the comparative legal method of investigation of certain provisions of Ukrainian legislation, the possibilities and limits of the use of cryptocurrency in contractual relations, in particular, contracts of purchase and sale are determined. The results of the study revealed that the cryptocurrency regime in Ukraine and in many countries is in a legal vacuum. Such a conclusion is based on the lack of clear legal clarification and consolidation of the concept and types of cryptocurrency in the relevant rules of the tax, banking, civil, and commercial law. In case of eliminating this gap, it is advisable to review the state policy on Bitcoin and its analogues. Practical implications. It is necessary and appropriate to introduce a corresponding license for cryptocurrency activities that can minimize the laundering of proceeds from crime or terrorism financing. It is suggested that eventually the relations concerning the digital currency will be regulated in Ukraine, but most likely, it will copy the experience of another state, which may have negative consequences. Relevance/originality. Analysis of a possible use of cryptocurrency in contracts of purchase and sale can become the basis for the development of the most promising directions of domestic civil law in contractual relations.
\end{abstract}

Key words: cryptocurrency, purchase and sale, transaction, licensing, Bitcoin, cryptoexchange, cryptomarket.

JEL Classification: E42, E44, F63

\section{Problem statement}

The world is changing: former unusual dreams and ideas gradually become reality, many new and varied phenomena and processes arise. People of nowadays are faced with the requirement to adapt quickly and effectively to innovations. This is especially true in settlements and payments, as they are often used and directly related to the development of the economy, the state and well-being of the population. The circulation and creation of cryptocurrency require considering the issue of its legal regulation at the national and international levels. Many obstacles occur and need to be overcome in the future. Obviously, many people do not know and do not conceive the possible existence of cryptocurrencies. The next dilemma is the lack of discussion and elaboration of the essence of Bitcoin and its analogues by the state authorities when adopting laws or other normative acts. The specific nature of cryptocurrency leads to the fact that the relevant issue is not a priority for resolution. Nevertheless, now the world tendencies and realities force to change the attitude to this problem (Kryptovaliuta: ii pravovyi rezhym, problemy zastosuvannia).

The more popularity Bitcoin gains, the more necessity to discuss it at the international level occurs, moreover, the governments of individual countries have to reckon with it. Some countries have even recognized Bitcoin as currency. For example, in Switzerland since 2013, Bitcoin is considered a foreign currency. However, the majority tends to recognize Bitcoin as a property asset, operations with which must be taxed (Bitkoin, blokchein i maininh. Komu potribna kryptovaliuta i yak

\footnotetext{
Corresponding author:

${ }^{1}$ Department of Research Work Organization, National Academy of Internal Affairs.

E-mail: alex0674682444@gmail.com

${ }^{2}$ Department of Civil Law and Procedure, National Academy of Internal Affairs.

E-mail: basay_ov@gmail.com

${ }^{3}$ Department of Civil Law and Procedure, National Academy of Internal Affairs.

E-mail: alex0674682444@gmail.com
} 
derzhavy ii kontroliuiut). The United States, Germany, Japan, France, Finland, and other countries have not only allowed the circulation of the currency but also legislated or backed up the legal regime, clarified the notion of Bitcoin and analogues and formed the relevant judicial practice (Kryptovaliuta: ii pravovyi rezhym, problemy zastosuvannia).

Literature review. The study of the phenomenon of cryptocurrency (Bitcoin) is under consideration in the works of scientists such as Aiganym Y. Seitim, O.S. Badzym, Yu.V. Hava, B.V. Derevianko, A.R. Drevush, I.M. Doronin, O.O. Loviak., L.L. Neskorodzhena, O.O. Poplavskyi, N. Pantielieieva. Obviously, most of the researches of this issue are related to the scientific works of specialists in economics, although recently the attention of lawyers is also drawn to it.

The aim of the article. To consider the theoretical and legal possibilities of using cryptocurrency in the contracts of purchase and sale. To determine the specificities of such a phenomenon as cryptocurrency (Bitcoin) from the perspective of jurisprudence and draw the attention of legal scholars primarily to possible further scientific researches on the introduction of this phenomenon in the modern legislation of Ukraine.

The main material. The main problem faced by international financial organizations and the leadership of certain countries is the control over the circulation of cryptocurrency since uncontrolled it creates a large space for the development of the shadow economy (Bitkoin, blokchein i maininh. Komu potribna kryptovaliuta i yak derzhavy ii kontroliuiut).

In addition, the unregulated sphere of cryptocurrency provides fraudsters with great opportunities, because intruders' actions cannot be classified and, therefore, punished if relevant legislation is absent in the country. For example, if you bought a product for Bitcoin and you did not get it, then you came with it to law enforcement agencies, but neither the police nor the court would manage your case (Bitkoin, blokchein i maininh. Komu potribna kryptovaliuta i yak derzhavy ii kontroliuiut).

However, according to an expert, the founder of the first Bitcoin agency in Ukraine, Mykhailo Chobanian, in Ukraine Bitcoin still does not have a definite legal status (Shcho take elektronna valiuta 'Bitkoin'?). Chobanian notes that there are only a few countries in the world where the status is defined, the last country where the status has become a noteworthy case is the United States, where it is recognized as a commodity, financial instrument, it is now a full-value instrument in the financial market (Shcho take elektronna valiuta 'Bitkoin'?).

In Ukraine, the problem of legal regulation of cryptocurrency is ambiguous regulation of cryptocurrency in the world. Countries with a strong economy and currency introduce cryptocurrency as a means of payment or financial asset. Countries with a weak economy and an unstable monetary unit are trying to support the national currency by restricting cryptocurrency as a means of payment but allowing cryptocurrency as a means of exchange (Kryptovaliuta: ii pravovyi rezhym, problemy zastosuvannia).

For example, in some states of the USA, cryptocurrency is the subject of money transfers in the payment system. In Germany, Bitcoin is recognized as a unit of account. In Japan, cryptocurrency is recognized as legal tender. In Europe, cryptocurrency is generally equated with electronic money but is not considered legal tender and is a means of exchange. In China, transactions with Bitcoin are prohibited for banks but allowed for individuals. In Canada, bitcoin is a means of account. In Spain, the Bitcoin system is recognized as an official payment system. Direct bans on cryptocurrency usage exist in Bolivia, Ecuador, Thailand, and Vietnam (Kryptovaliuta: ii pravovyi rezhym, problemy zastosuvannia).

Thus, the ambiguous approach to cryptocurrency in different countries of the world creates additional problems for determining the legal status of cryptocurrency. This means that Ukraine needs to develop its own approach to the legal regulation of cryptocurrencies, giving them a special legal status, based on the current state of law and economic development of the country (Kryptovaliuta: ii pravovyi rezhym, problemy zastosuvannia).

According to statistics, in 2016, the conversion of cryptocurrency into the national currency amounted to 775.2 million $\mathrm{UAH}$, while the introduction of the national currency on the stock exchange of cryptocurrency was 856.8 million UAH. In 2016 only, the demand for cryptocurrency in Ukraine grew by 5 times, and by the number, for example, of Bitcoin-wallets, Ukraine is among the top 5 world leaders. (Kryptovaliuta: ii pravovyi rezhym, problemy zastosuvannia).

Therefore, the special regime for Bitcoin in Ukraine is not established, because the aforementioned question on cryptocurrency has not been aroused when discussing and adopting laws. According to the explanation in a letter from the NBU of December 8, 2014, defines Bitcoin as a "money surrogate" that has no real value and cannot be used by individuals and legal entities in Ukraine as a means of payment since it contradicts to the norms of Ukrainian legislation (Kryptovaliuta: ii pravovyi rezhym, problemy zastosuvannia).

To find out the legal nature of Bitcoin it is important to note that the law "On the National Bank of Ukraine" states that the money surrogate is any documents in the form of banknotes that are different from the monetary unit of Ukraine issued in circulation not by the NBU and made for payments in economic circulation. Meanwhile, specificities of cryptocurrency are not covered by the term "electronic document" since the latter refers to a document, which records information in the form of electronic data, taking into account the required details 
of the document. Thus, a money surrogate does not consider the concept of cryptocurrency.

On the one hand, Bitcoin can be seen as a set of information. It is based on a blockchain-encrypted array of data about all operations that have been conducted in a distributed network during its entire existence. On the other hand, Bitcoin is close to the product, because the national legislation does not provide for a clear definition of the product as such, but denotes only a part of this concept for specific legal relationships. Another positive aspect is that cryptocurrency is a subject to barter (commodity exchange) transactions as perceived by the Tax, Civil, and Commercial Codes of Ukraine. Nevertheless, judicial practice goes the opposite way. For example, in the decision of the Darnytskyi District Court of Kyiv No. 753/599/16-ts, Bitcoin was not recognized as a commodity (Kryptovaliuta: ii pravovyi rezhym, problemy zastosuvannia).

Therefore, it is the most expedient to find out the essence of cryptocurrency, discuss it and receive relevant explanations from the state body before making appropriate changes to Ukrainian legislation (Kryptovaliuta: ii pravovyi rezhym, problemy zastosuvannia). Obviously, nowadays, the main problem of regulating legal relations with cryptocurrency is the lack of relevant legislative rules that can be applied to cryptocurrency.

Another problem of cryptocurrency legal regulation in Ukraine is ambiguous regulation of cryptocurrency in the world. Countries with a strong economy and currency unit introduce cryptocurrency as a means of payment or as a financial asset. Countries with a weak economy and an unstable monetary unit try to support the national currency by restricting cryptocurrency as a means of payment, but allow cryptocurrency as a means of exchange.

For example, nowadays, the EU legislation categorizes Bitcoin as a digital representation of value, not confirmed by a central bank or government body and not attached to legally established exchange rates, and can be used as a means of exchange for the purchase of goods and services, their transfer and storage, and can be acquired electronically. Moreover, the exchange of traditional currencies per Bitcoin unit is exempt from paying valueadded tax. In Israel, Bitcoin is not provided for with the legal definition of currency, either as a financial security or as a taxable asset. Each time Bitcoin is sold, the seller must pay a capital gains tax. The People's Bank of China considers Bitcoin to be a virtual commodity, not currency, and its sale may be subject to VAT. Its sales are taxed by the Japanese VAT counterpart. In Australia, Bitcoin is considered a property, and transactions with it are barter. In Canada, Bitcoin is generally defined as an intangible asset, and transactions with it are also barter.

Thus, in different countries, Bitcoin is classified differently, for example, as virtual currency, money surrogate, intangible value, virtual goods, etc. For its part, the National Bank of Ukraine currently officially does not support any of the abovementioned definitions (Komentar zastupnyka Holovy NBU Oleha Churiia shchodo statusu Bitcoin v Ukraini).

Thus, an ambiguous approach to cryptocurrency in different countries of the world creates additional problems for determining the legal status of cryptocurrency. Consequently, Ukraine needs to develop its own approach to the legal regulation of cryptocurrency, providing it a special legal status, based on the current state of legislation and economic development of the country. According to statistics, in 2016, the withdrawal of cryptocurrency into the national currency amounted to 775.2 million UAH, while the introduction of the national currency on the stock exchange of cryptocurrency was 856.8 million UAH. In 2016 only, the demand for cryptocurrency in Ukraine grew by 5 times, and by the number, for example, of Bitcoin-wallets, Ukraine is among the top 5 world leaders (Kryptovaliuta: ii pravovyi rezhym, problemy zastosuvannia).

It is roughly estimated that today there are more than 2,000 types of cryptocurrencies, the most popular is Bitcoin. The total market capitalization of the Bitcoin market is estimated at 130 billion US dollars, and the aggregate volume of trading in such digital assets reaches 2.6 billion US dollars. Thus, it seems rather strange that cryptocurrency has become an indispensable part of social relations, financial instruments, business, but under no legal regulation. Considering the world practice, cryptocurrency is gaining popularity all over the world, its development is impossible to prohibit technically, moreover, it is economically inexpedient, and therefore, the legal regulation of cryptocurrency is now only a matter of time (Kryptovaliuty v Ukraini. Problemy ta perspektyvy pravovoho rehuliuvannia).

In the decision of October 22, 2015, the European Court determined that Bitcoin should be considered a currency (means of payment), and not a commodity. The rationale for this was some difficulties with the taxation of cryptocurrency. The corresponding decision established that all transactions related to Bitcoin exchange would be taxed in the same way as transactions with traditional currencies. Actually, European jurisprudence has equated cryptocurrency with legal means of payment, and the exchange of funds with "a currency exchange transaction." Nevertheless, according to the current legislation of the $\mathrm{EU}$, digital currency is considered to be a commodity and is regulated by the Civil Law and the EU Directive on the PIT as a commodity, and the contract of purchase and sale of cryptocurrency is a contract of purchase and sale of goods (Kryptovaliuta: ii pravovyi rezhym, problemy zastosuvannia).

In the trial of Antonio Murdjio of Coin.mx, Judge Alison Natean claimed that dictionaries, courts, as well as legal history, confirmed that Bitcoin is money. This 
point of view of American judges was confirmed by the department dealing with financial and criminal offenses, which in 2013 categorized Bitcoin as "a form of money." However, another influential American tax authority (Internal Revenue Service (IRS)) emphasized that for the purposes of federal taxation, cryptocurrency should be interpreted not as "a form of money" but as a property (Kryptovaliuta: ii pravovyi rezhym, problemy zastosuvannia).

In Ukraine, some favourable for Bitcoin judicial practice is being formed. For example, the decision of October 13, 2016, by the Kharkiv Administrative Court of Appeal equated all transactions conducted in E-Dinar Coin with ordinary money transactions (Kryptovaliuta: ii pravovyi rezhym, problemy zastosuvannia). In Ukraine, cryptocurrency transactions are subject to standard taxation. The question of the value added tax is rather controversial because cryptocurrency is not defined as goods at the legislative level (Kryptovaliuta: ii pravovyi rezhym, problemy zastosuvannia).

Therefore, cryptocurrency as an object of civil legal relations can be considered:

Article 177 of the Civil Code classifies types of civil rights objects, indicating that they include:

- things, including money and securities (according to Article 179 of the Central Committee, a thing is an object of the material world, in relation to which civil rights and obligations may arise);

- other property (according to Article 190 of the Central Committee, a property as a special object is a separate thing, a set of things, as well as property rights and obligations; property rights are non-consumable; property rights are recognized as real rights);

- the results of work (Chapter 61, 63 of the Central Committee);

- services (Chapter 63 of the Central Committee);

- the results of intellectual, creative activity (according to Article 199 of the Civil Code, the results of intellectual, creative activity and other objects of intellectual property rights create civil rights and obligations in accordance with book IV of the Central Committee (intellectual property right).

- information (according to Part 1 of Article 200 of the Central Committee, the information is any facts and/or data that can be stored on tangible media or displayed electronically. The legal status of information is determined by special laws, in particular, the Law of Ukraine “On Information” No. 2657-XII of October 2, 1992);

- other tangible and intangible benefits (such as personal intangible goods protected by civil law. In particular, according to Part 1 of Article 201 of the Civil Code, such are life and health, honour, dignity and business reputation, the name (denomination), authorship, freedom of literary, artistic, scientific and technical creativity, as well as other goods protected by civil law).
Therefore, cryptocurrency is difficult to attribute to any type of objects of civil and legal relations, and consequently, such a situation means a gap in the law: to the legal relationship with cryptocurrency, it is impossible to apply directly this or that rule of the current legislation. Thus, in current conditions, the only way to apply the analogy of law or analogy of legality is as follows: if civil relations are not regulated by this Code, other acts of civil law or the contract, they are governed by the legal rules of this Code, other acts of civil law governing civil relations of similar content (analogy of law). In case of impossibility to use the analogy of law for regulating civil relations, they are regulated in accordance with the general principles of civil law (analogy of legality) (Article 8 of the Civil Code). However, it is still unresolved, what kind of legal relations can be applied by analogy to cryptocurrency?

Nowadays, according to Part 1 of Article 99 of the Constitution of Ukraine, the monetary unit of Ukraine is hryvnia. According to Clause 3.3 of Article 3 of the Law of Ukraine of April 5, 2001 No. 2346-III "On Payment Systems and Transfer of Funds in Ukraine," Part 1 of Article 3 of the Decree of the Cabinet of Ministers of Ukraine "On the System of Currency Regulation and Currency Control" No. 15-93 of February 19, 1993, hryvnia as the monetary unit of Ukraine (the national currency) is the only legal means of payment in Ukraine accepted by all individuals and legal entities without any restrictions on the entire territory of Ukraine for transfers. According to Clause 14.1.93 of the Tax Code of Ukraine, funds mean hryvnia or foreign currency.

According to Part 1 of Article 2 of the above-mentioned Decree of the Cabinet of Ministers of Ukraine "On System of Currency Regulation and Currency Control," residents and non-residents have the right to be owners of currency values located on the territory of Ukraine. Residents also have the right to be owners of currency values outside Ukraine, except for cases provided for by the legislative acts of Ukraine. The list of currency values is indicated in Article 1 of the abovementioned Decree, including the currency of Ukraine, payment documents and other securities, denominated in the currency of Ukraine; foreign currency, payment documents and other securities denominated in foreign currency or banking metals; banking metals.

Therefore, cryptocurrency according to Ukrainian legislation cannot be equated with either a means of payment or currency value.

In this regard, the National Bank noted that the issuance of the virtual currency Bitcoin has neither security nor legal binds on individuals, is not controlled by the state authorities of any country. Thus, Bitcoin is a money surrogate that does not provide real value (the Letter of the National Bank "On the assignment of operations with virtual currency/cryptocurrency Bitcoin to foreign exchange transactions, as well as the availability of grounds for enrolment on a current 
account in foreign currency of a physical person foreign currency received from the sale of Bitcoin" No. 29-208/72889 December 8, 2014).

In addition, in another Letter, the NBU emphasized that the issue and circulation of other monetary units in the territory of Ukraine and the use of money surrogates as a means of payment are prohibited (Part 2 of Article 32 of the Law of Ukraine "On the National Bank of Ukraine"). Taking into account the above, the National Bank of Ukraine considers virtual currency/ cryptocurrency Bitcoin as a money surrogate, which has no real value and cannot be used by individuals and legal entities in the territory of Ukraine as a means of payment, because this contradicts to the rules of Ukrainian legislation. Moreover, currency/cryptocurrency Bitcoin usage is accompanied with a high risk factor in this service, transaction or delivery channel, such as the anonymity of transactions (which may include cash), decentralization of operations (Clarification of the National Bank of Ukraine "Clarification on the legality of the use of virtual currency/cryptocurrency Bitcoin in Ukraine" of November 10, 2014).

Furthermore, the NBU claimed that the sale of Bitcoin for US dollars or other foreign currency has signs of the functioning of the so-called "financial pyramids" and may indicate potential involvement in the implementation of dubious transactions in accordance with the legislation on counteraction to legalization (laundering) of proceeds obtained from crime and terrorism financing (the Letter of the National Bank "On the assignment of operations with virtual currency/cryptocurrency Bitcoin to foreign exchange transactions, as well as the availability of grounds for enrolment on a current account in foreign currency of a physical person foreign currency received from the sale of Bitcoin” No. 29-208/72889 on December 8, 2014).

Perhaps, cryptocurrency is electronic money? In Article 15 of the Law of Ukraine of April 5, 2001 No. 2346-III "On Payment Systems and Transfer of Funds in Ukraine," electronic money is defined as units of value stored on an electronic device, accepted as a means of payment by other persons than the person issuing them, and monetary obligation of this person, executed in cash or in non-cash form. The issue of electronic money can be carried out exclusively by the bank. The bank issuing electronic money undertakes the obligation to repay it (also regulated by the Regulation on electronic money in Ukraine, approved by the Resolution of the Board of the National Bank of Ukraine on November 4, 2010, No. 481 "On Amendments to Certain Regulatory and Legal Acts of the National Bank of Ukraine on Regulation of Issuance and Circulation of Electronic Money").

The main differences between cryptocurrency and electronic money are:

- cryptocurrency does not mean the debt obligations of its holder, owner or issuer (as noted above, the issuer of cryptocurrency does not exist at all);
- in the system of cryptocurrency, there is no single emission centre or central administrator;

- payments within the system of certain cryptocurrency can be carried out absolutely anonymously, so taxpayers and recipients of cryptocurrency are not controlled completely by any third parties, including state bodies (because the electronic keys used when identifying the parties to settlements with cryptocurrency do not contain any personal data of such participants of settlements and, therefore, it is impossible to define and identify such parties of settlements);

- the process of creation of new types of cryptocurrency or increase of the volume of cryptocurrency within a single cryptocurrency system (the process of mining) is possible, therefore, the number of units of cryptocurrency may increase exorbitantly without additional binding to any liability for such cryptocurrency, and may be carried out based on mathematical algorithms using computational power of computers belonging to individuals who extract (mine) additional cryptocurrency units. Accordingly, the lower rate of generation of new cryptocurrency units, the higher total mass of cryptocurrency is, along with the generation of additional cryptocurrency units, in case of reaching a certain total number of units, will become technically impossible (for example, in case of reaching 21 million bitcoin units);

- electronic money has an obligatory attaching to a certain national currency and the issuer, while cryptocurrency cannot be equated with any currency of the world, being a kind of independent currency.

Therefore, cryptocurrency is not electronic money and cannot be equated with it yet (Kryptovaliuty v Ukraini. Problemy ta perspektyvy pravovoho rehuliuvannia). Let us equate cryptocurrency with a financial asset or a financial service object:

According to Article 1 of the Law of Ukraine "On Financial Services and State Regulation of Financial Services Markets” No. 2664-III of July 12, 2001, financial services are defined as transactions with financial assets carried out in the interests of third parties at their own expense or at the expense of those persons, and in cases provided by law, due to borrowed from other persons financial assets, in order to profit or maintain the real value of financial assets.

In this case, financial assets are means, securities, debentures and debt claims that are not attributed to securities. The list of financial services is defined in Article 4 of the abovementioned Law (the subject of financial services must necessarily be a financial asset).

Each type of financial assets is regulated by the general and special legislation. With regard to the legal regulation of cryptocurrency as money (means of payment) or currency values, this is already discussed above.

Regarding the legal regime of securities, the legal circulation of securities and their exhaustive list is 
established by Articles 194-198 of the Civil Code, as well as by the special Law of Ukraine "On Securities and the Stock Market” No. 3480-IV of February 23, 2006. The obligatory feature of a security is the presence of the issuer of the security (issuing person) and the certificate of monetary or other property rights between the person having the rights to the security and its issuer.

Therefore, based on the specificities of the functioning and issuance of cryptocurrency, in particular, the lack of an issuer, as well as the absence of debt obligations for the cryptocurrency, as noted above, the legal regime of securities and debt obligations for cryptocurrency cannot be applied (Kryptovaliuty v Ukraini. Problemy ta perspektyvy pravovoho rehuliuvannia).

Is cryptocurrency a program code and an object of intellectual property rights?

Cryptocurrency is a set of program code, the accounting and operation of which are based on the encryption and application of various cryptographic methods of protection, so the rights to such program code are often equated with the rights to software with the appropriate legal regulation. However, the main problem with this approach is the absence of the author of such a code since the issue of cryptocurrency is decentralized and automated, the single issuer of cryptocurrency is absent. Thus, it is not correct to assert that cryptocurrency is a software or object of intellectual property rights (for example, the according to Articles 418, 420, 421 of the Civil Code, Articles 1, 8, 11, 18 of the Law of Ukraine "On Copyright and Related Rights"). Accordingly, over the lack of an author on such a program code, it will be impossible to regulate cryptocurrency as an object of intellectual property rights (in particular, as a program), and therefore, the legislation on the transfer of rights to intellectual property rights cannot be applied to cryptocurrency rights transfer operations (Kryptovaliuty $\mathrm{v}$ Ukraini. Problemy ta perspektyvy pravovoho rehuliuvannia).

Currently, two Draft Laws are registered in the Verkhovna Rada concerning the legal status and circulation of cryptocurrency:

- the Draft Law of Ukraine on October 10, 2017 No. 7133-1 "On Stimulation of the Market for Cryptocurrency and Their Derivatives in Ukraine" (Author of the legislative initiative S. Rybalka);

- the Draft Law of Ukraine on October 10, 2017 №7133 "On Circulation of Cryptocurrency in Ukraine" (Authors of the legislative initiative: I. Efremov, L. Denisov, I. Kotvitskyi, I. Rybak, and S. Voitsekhovska).

The Draft Law of Ukraine on October 10, 2017 No. 7133-1 "On Stimulation of the Market for Cryptocurrency and Their Derivatives in Ukraine" defines cryptocurrency as a decentralized digital value measurement that can be denominated in numerical form and functions as a means of exchange, a store of value or a unit of account, based on mathematical calculations being their result and has cryptographic protection of accounting. For legal regulation, cryptocurrency is considered a financial asset. The Draft provides for the introduction of a $2 \%$ tax for compulsory state pension insurance for each crypto-exchange transaction, which will result in additional revenues to the State Budget of Ukraine (Kryptovaliuty v Ukraini. Problemy ta perspektyvy pravovoho rehuliuvannia).

The Draft Law No. 7133 "On Circulation of Cryptocurrency in Ukraine" provides for that cryptocurrency is a program code (a set of characters, numbers, and letters) that is the subject of a property right that may act as a means of exchange, the information of which are entered and stored in the blockchain system as accounting units of the current block system as data (program code). Moreover, the Draft states that the general rules, provided for to private ownership, can be applied to cryptocurrency, while to cryptocurrency transactions the general provisions of the contract of exchange are applied in accordance with the legislation of Ukraine. In addition, the Draft provides for the distribution of tax legal relations to operations on mining and exchange of cryptocurrency, in accordance with the current legislation of Ukraine (i.e. cryptocurrency will be the subject of taxation) (Kryptovaliuty v Ukraini. Problemy ta perspektyvy pravovoho rehuliuvannia).

Both Draft Laws need to be further elaborated, first of all, in view of the necessity to amend the other legislative acts regulating the related legal relations (in particular, the Civil Code of Ukraine) in parallel, by providing the definition and legal status of cryptocurrency as a special object of civil law relationships. Moreover, at the state level, it is necessary to develop programs for the introduction of special software, which will allow the circulation of cryptocurrency, for example, as a subject of exchange. In addition, definitely, cryptocurrencies should be subject to taxation, which will create additional revenues for the State Budget of Ukraine (Kryptovaliuty v Ukraini. Problemy ta perspektyvy pravovoho rehuliuvannia).

However, the regulator, the National Securities and Stock Market Commission refused to support these Draft Laws in their initially filed form. The Commission draws attention to the inadmissibility of the use of the term "cryptocurrency" since in essence this concept is the result of financial engineering, not "currency" (Bitcoin v Ukraini: NBU ta inshi rehuliatory vyznachylysia zi statusom kryptovaliut). According to the State Agency for e-Government, in Ukraine, for the first time in the world, an electronic transatlantic exchange agreement was signed in cryptocurrency Ethereum with the use of the Ethereum Blockchain smart contract. Eizvestia. com informs that the amount of the transaction is equated with USD 60,000. Apartment owner Mark Ginzburg (lives in New York) sold an apartment in Kyiv through his representative. The Propy Startup in the Silicon Valley became the platform for the transaction. 
According to The Wall Street Journal, the buyer was Michael Arrington, a founder of TechCrunch (and also an advisor at Propy) (Vpershe v Ukraini ofitsiino prodaly kvartyru za kryptovaliutu). Before concluding a deal through Blockchain, the parties signed a smart contract. The address of the smart contract is shown in the contract, which is submitted directly to the property register and in the blockchain Ethereum (Vpershe $\mathrm{v}$ Ukraini ofitsiino prodaly kvartyru za kryptovaliutu).

On the Propy platform, the seller and the buyer have contracted intention, on the basis of which cryptocurrency was transferred into a deposit. Subsequently, the lawyers prepared the necessary documents for the transaction of sale and purchase, property valuation acts were ordered, power of attorney was issued to the parties, and also a notarial agreement was made. After entering changes of rights of the ownership to the register, an extract from it was received. In turn, the extract was immersed in the system, which enabled to unlock the smart contract and remit the required amount to the seller (Vpershe $\mathrm{v}$ Ukraini ofitsiino prodaly kvartyru za kryptovaliutu).

\section{Conclusions}

To sum up, it should be emphasized that the regime of cryptocurrency in Ukraine and in many countries is in a legal vacuum. Consequently, every consumer and legislator should have had open information about the issuer, the order of issue and cryptocurrency transactions. Then reviewing of the state policy on Bitcoin and analogues would be possible. In addition, a question of legislative clarification and consolidation of this concept through the adoption of relevant rules in tax, banking, civil and commercial law occurs. Moreover, it is necessary and expedient to introduce the appropriate license for cryptocurrency activities that would minimize money laundering or terrorism financing. Someday, relations with respect to the digital currency will be resolved, but most likely it will be an inappropriate and unjustified copying of the experience of another state, which may have negative consequences. That is why it should be considered that the legal regime of cryptocurrency ought to be adapted to the actual world events and the real situation in the state (Lozova, Loviak, 2018; Dudko, Loviak, 2017; Motyl, Loviak, 2018).

\section{Further scientific research:}

the possibility of the occurrence and implementation of material liability. Labour relations develop quite quickly; possibly, in the future, freelance workers will receive wages in cryptocurrency or compensate for damage to the enterprise, taking into account the cost of Bitcoin.

By no means, reflections, presented in the article, put the end in the study of problems of cryptocurrency relations. The problems outlined need further study, while scientific achievements should be implemented in the social and legal life.

\section{References:}

Kryptovaliuta: ii pravovyi rezhym, problemy zastosuvannia [Cryptocurrency: its legal regime, application problems]. Retrieved from http://ukrainepravo.com/legal_publications/essay-on-it-law/it_law_plyta_\% D1\%81ryptocurrency/

Bitkoin, blokchein i maininh. Komu potribna kryptovaliuta i yak derzhavy ii kontroliuiut [Bitcoin, blockchain and mining. [Who needs cryptocurrency and in what manner the states monitor it]. Retrieved from https://tsn.ua/groshi/bitkoyin-blokcheyn-i-mayning-komu-potribna-kriptovalyuta-i-yak-derzhavi-yiyikontrolyuyut-1016475.html

Shcho take elektronna valiuta 'Bitkoin'? [What is it Bitcoin currency?] Retrieved from https://www.radiosvoboda.org/a/27271364.html

Kryptovaliuty v Ukraini. Problemy ta perspektyvy pravovoho rehuliuvannia [Cryptocurrency in Ukraine. Problems and prospects of legal regulation]. Retrieved from http://yur-gazeta.com/publications/practice/informaciynepravo-telekomunikaciyi/kriptovalyuti-v-ukrayini-.html

Vpershe v Ukraini ofitsiino prodaly kvartyru za kryptovaliutu [For the first time in Ukraine officially an apartment was sold for cryptocurrency]. Retrieved from http://eizvestia.com/uk/news_economy-ukr/full/2709-vpershe-vukraini-oficijno-prodali-kvartiru-za-kriptovalyutu

Shchodo vidnesennia operatsii z 'virtualnoiu valiutoiu/kryptovaliutoiu Bitcoin' do operatsii z torhivli inozemnoiu valiutoiu, a takozh naiavnosti pidstav dlia zarakhuvannia na potochnyi rakhunok v inozemnii valyuti fizychnoi osoby inozemnoi valiuty, otrymanoi vid prodazhu Bitcoin: Lyst Natsionalnoho banku Ukrainy vid 08.12.2014 № 29-208/72889 [On classification the transactions with 'virtual currency / cryptocurrency Bitcoin' in transactions with foreign currency trade, as well as the grounds for enrolment on a current account in foreign currency of an individual foreign currency obtained from the sale of Bitcoin: Letter of the National Bank of Ukraine of August 12, 2014 No. 29-208/72889]. Biznes-Bukhhalteriia-Pravo. Podatky. Konsultatsii. [Business-Accounting-Law. Taxes. Consultation]. (2015). 37, 26.

Roziasnennia shchodo pravomirnosti vykorystannia v Ukraini 'virtualnoi valiuty /kryptovaliuty' Bitcoin: Roziasnennia NBU vid 10.11.2014 [Clarification on the legality of using 'virtual currency / cryptocurrency' Bitcoin in Ukraine: Clarification of the NBU]. (November 10, 2014). Retrieved from http://zakon.rada.gov.ua/ laws/show/n0435500-14/card6\#Public 
Pro obih kryptovaliuty v Ukraini: Zakonoproekt №7183 vid 06.10.2017 [On the Circulation of Cryptocurrency in Ukraine: Draft Law No. 7183]. (October 06, 2017) Retrieved from http://w1.c1.rada.gov.ua/pls/zweb/ webproc4_1?pf3511=62684

Komentar zastupnyka Holovy NBU Oleha Churiia shchodo statusu Bitcoin v Ukraini [Commentary of the Deputy Chairman of the National Bank of Ukraine Oleg Churii on the status of Bitcoin in Ukraine]. Retrieved from https://bank.gov.ua/control/uk/publish/article?art_id=53411806\&cat_id=55838

Bitcoin v Ukraini: NBU ta inshi rehuliatory vyznachylysia zi statusom kryptovaliut [Bitcoin in Ukraine: the NBU and other regulators have defined the status of cryptocurrency]. Retrieved from http://biz.nv.ua/ukr/finance/ bitcoin-v-ukrajini-nbu-i-inshi-reguljatori-viznachilisja-zi-statusom-kriptovaljuta-2293048.html

Lozova, T.I., Loviak, O.O. (February, 2018). Okremi aspekty obihu kryptovaliuty v Ukraini (tsyvilno-pravovyi aspekt) [Some aspects of the cryptocurrency circulation in Ukraine (civil and legal aspect)]. Jurnalul juridic național: teorie și practică [National Legal Journal: theory and practice]. (Moldova), 1(1), 104-108.

Dudko, A.H., Loviak, O.O. (2017). Bitcoin - obiekt tsyvilnykh prav chy innovatsiina posluha u sferi rozrakhunkiv (tsyvilno-pravove ese) [Bitcoin is an object of civil rights or an innovative service in the field of settlements (civil law essay)] Naukovyi visnyk publichnoho ta pryvatnoho prava: Zbirnyk naukovykh prats [Scientific Bulletin of Public and Private Law: Collection of Scientific Papers], 5(1). K.: Naukovo-doslidnyi instytut publichnoho prava [Research Institute of Public Law], 97-101.

Motyl, V.I., Loviak O.O. (2018). Okremyi pohliad na pravovyi rezhym kryptovaliuty v Ukraini A point of view on the legal regime of cryptocurrency in Ukraine In S.V. Hubariev, I.S. Timush (Eds.), Suchasni pohliady na aktualni pytannia pravovykh nauk: materialy mizhnarodnoi naukovo-praktychnoi konferentsii (23 lyutoho $2018 \mathrm{r}$.) [Current views on topical issues in the legal sciences: materials of the international scientific and practical conference (February 23, 2018)]. K: FOP Kandyba, 20-26. 